\title{
INEQUITY IN UTILIZATION OF HEALTH SERVICE BY INSURANCE STATUS AND INCOME LEVEL AT GAMPING MUHAMMADIYAH HOSPITAL, YOGYAKARTA: A PATH ANALYSIS EVIDENCE
}

\author{
R. Haryo Nugroho'), Bhisma Murti'), Arif Suryono²) \\ ${ }^{1)}$ Masters Program in Public Health, Universitas Sebelas Maret \\ ${ }^{2)}$ Faculty of Law, Universitas Sebelas Maret
}

\begin{abstract}
Background: Inequitable access to quality healthcare is a major health policy challenge in many low- and middle-income countries. Health insurance is an important as a cost effective method of protecting against unexpected health issues, removing the financial barriers, and improving accessibility to quality health care. This study aimed to examine the equity in utilization of health service by insurance status and income level using path analysis model.

Subjects and Method: A cross-sectional study was carried out at PKU Muhammadiyah hospital, Gamping, Sleman, Yogyakarta. A sample of 200 patients was selected by simple random sampling. The dependent variable was frequency of health care utilization. The independent variables were health insurance status, income, education, and residence. The data were collected by questionnaire and analyzed by path analysis.

Results: Frequency of health care utilization was directly and positively affected by health insurance status $(b=2.75 ; \mathrm{SE}=0.54 ; \mathrm{p}<0.001)$ and residence $(b=1.77 ; \mathrm{SE}=0.33$; $\mathrm{p}<0.001)$. It was indirectly and positively affected by income and education.

Conclusion: The utilization of health service is inequitable with respect to insurance status and income level. Those insured used health service more than those uninsured. Those with higher income used health service more than those with lower income.
\end{abstract}

Keywords: health service, utilization, health insurance

Correspondence:

R. Haryo Nugroho. Masters Program in Public Health, Universitas Sebelas Maret. Jl. Ir. Sutarmi 36A, Surakarta 57126, Central Java. Email: haryo_sleman@yahoo.co.id. Mobile: 08122504214.

The $6^{\text {th }}$ International Conference on Public Health Best Western Premier Hotel, Solo, Indonesia, October 23-24, 2019 | 261 https://doi.org/10.26911/the6thicph.04.23 